\title{
Do protein hydrolysates improve survival and growth of newly-hatched spotted wolffish (Anarhichas minor), a non-metamorphic aquaculture fish species?
}

\author{
A. Savoie ${ }^{a}$, N.R. Le François ${ }^{a, b,}$, C. Cahu ${ }^{c}$, P.U. Blier ${ }^{b}$ and I. Andreassen ${ }^{d}$ \\ ånépartement de biologie et des Sciences de la Santé, Université du Québec à Rimouski, QC, \\ Canada, G5L 3A1 \\ ${ }^{\mathrm{b}}$ Ministère de l'Agriculture, des Pêcheries et de l'Alimentation du Québec, Centre aquacole marin, \\ Grande-Rivière, QC, Canada, G0C 1V0 \\ ${ }^{c}$ Unité Mixte INRA IFREMER de Nutrition des Poissons, B.P. 70, 29280 Plouzané, France \\ ${ }^{\mathrm{d}}$ Troms Steinbit, Rubbestad, Vangsvik, Norway \\ *: Corresponding author : Nathalie_Le-Francois@uqar.qc.ca
}

\begin{abstract}
:
Despite larval robustness characterized by the absence of metamorphosis and readiness for exogenous feeding based on commercial feed, the spotted wolffish (Anarhichas minor) displays highly variable survival at first-feeding. In this study, we investigated the use of three dietary concentrations of protein hydrolysates ( $\mathrm{PH}$, pre-digested proteins) (0, 10 and $20 \%$ ) when newly hatched juvenile wolffish were held at three different rearing temperatures namely, 5,8 and $12{ }^{\circ} \mathrm{C}$ to determine whether digestion of protein was a limiting factor for fish growth and survival. Final weights for fish at 5, 8,and $12{ }^{\circ} \mathrm{C}$ at day 60 were respectively $0.35,1.19$ and $2.02 \mathrm{~g}$. Mean specific growth rates were $1.97,4.01$ and $4.88 \%$ /day and survival rates were $49.8,53.4$ and $33.2 \%$ respectively. No significant effects of $\mathrm{PH}$ were observed on growth or survival at any time during the experiment. However, as a general trend, fish survival was always higher when the diet contained $20 \% \mathrm{PH}$. We suggest that the degree of hydrolysis of the $\mathrm{PH}$ used may have been insufficient to induce specific digestive enzyme stimulation for promoting larval growth. Moreover, precocious ontogeny of the digestive system may have precluded any significant effect of using dietary protein hydrolysates. Our results are discussed in comparison with metamorphic species which characteristically display incomplete development of the digestive system.
\end{abstract}

Keywords: Anarhichas minor; Spotted wolffish; Protein hydrolysates; First feeding; Growth; Survival 


\section{Introduction}

Spotted wolffish is a marine fish species extremely well suited for cultivation under cold northern climates (Le François et al.; 2002, Foss et al., 2004). Research efforts can be qualified as recent and have mainly been conducted in northern Norway where one commercial facility is in operation (http://www.tommamarinfisk.no). In the east of Québec, Canada, research on spotted wolffish cultivation in collaboration with Norway, Iceland and Newfoundland is ongoing since 1999 and a project aimed at the creation of an experimental farm (production of 10-20 metric tons) is actually under evaluation. The advantages of raising this species and to include it in a mariculture diversification strategy, resides in 1) their high growth rate at cold water temperature, 2) the low complexity of the larval-juvenile period and 3) their farming-friendly behaviour, all of which should facilitate technological transfer to an aquaculture industry currently solely based on salmoniculture. However, despite larval robustness characterized by large egg and larval size, the absence of metamorphosis and readiness for exogenous feeding, high variability of survival at first-feeding is frequently reported : 18-32\% (Falk-Petersen et al. (1999), 47-64\% (Hansen and Falk-Petersen, 2002), 12-30\% (Hansen and Falk-Petersen, 2001), 88-96\% (Hansen and FalkPetersen, 2001b). Observed variability in survival at first-feeding can be attributable to variable egg quality, development of digestive capacities and/or feed formulation (Falk-Petersen et al., 1999; Lamarre et al., 2004).

Digestive capacity has been proposed as a factor limiting growth rate and survival in larval fish (Gisbert et al., 1999; Sharma and Chakrabarti, 1999; Gawlicka et al. , 2000). Many authors hypothesized that growth capacity could be limited by digestion and nutrient transport capacities (Houlihan et al., 1988; Blier et al., 1997; Lemieux et al., 1999). More specifically, trypsin activity, a key-enzyme of protein digestion, has been correlated to growth rate (Cyprinus carpio: Sharma et Chakrabarti, 1999; Gadus morhua: Lemieux et al., 1999) and survival (Anarhichas lupus: Lamarre et al. 2004). If digestive capacity is a limiting factor at first-feeding for the spotted wolffish, providing the newly hatched fish a more digestible diet should improve both growth and survival since amino acids from dietary proteins are absorbed mainly as peptides or amino acids (Silk et al., 1985; Rust et al., 1995; Ronnestad, 2001). Protein hydrolysates (PH), are pre-digested protein, known to enhance larval performances of several fish species based on the assumption that an "immature" digestive system limits nutrient absorption (Hardy, 2000). In several species, inclusions of $\mathrm{PH}$ have been reported to have positive effect on larval performances (Szlaminska et al., 1993; Cahu et Zambonino Infante, 1995; Carvalho et al., 1997; Zambonino Infante et al., 1997). Spotted wolffish, a non-metamorphic species, displays a welladvanced digestive apparatus at hatching i.e. a twisted and differentiated digestive tract (FalkPetersen and Hansen, 2001). However, due to high variability in survival and growth at firstfeeding, we propose to investigate if early-life performances might be limited by protein digestion capacities and furthermore state on the relevance of $\mathrm{PH}$ inclusion to improve earlyrearing performances of this novel aquaculture fish species.

In an attempt to increase the possibility of detecting beneficial effects of PH supplementation, we modulated the growth rate and survival response by using a range of rearing temperatures: 5, 8 and $12{ }^{\circ} \mathrm{C}$. Based on a literature review, fish reared at $5{ }^{\circ} \mathrm{C}$ should display impaired growth whereas fish reared at $12{ }^{\circ} \mathrm{C}$ should display higher growth compared to fish reared at $8{ }^{\circ} \mathrm{C}$, which is a regarded as a near optimal temperature for newly-hatched spotted wolffish for optimal growth and survival during the first 60 days (Hansen and Falk-Petersen, 2002). The nutritional requirements of wolffish have not been thoroughly investigated (Foss, 2004). To our knowledge, 
the effect of adding pre-digested proteins to the feed on growth or survival combined to the effect of temperature has never been tested on any marine fish species. In addition, we selected spotted wolffish as a non-metamorphic aquaculture marine fish species in order to compare the growth and survival response compared to the more studied metamorphic species. Our assumptions are that if protein digestion capacities are a limiting factor of growth and survival, PH supplementation will have a limited positive effect on growth or survival at optimal temperature $\left(8{ }^{\circ} \mathrm{C}\right)$ and some effect at 5 and $12{ }^{\circ} \mathrm{C}$. Three levels of $\mathrm{PH}$ (0, 10 and 20\%) were tested at all experimental temperature.

\section{Material and methods}

Experimental animals and rearing conditions

The study was carried out at the aquaculture facilities of the Centre Aquacole Marin, GrandeRivière, Québec, Canada. Fertilized eggs from three different females provided by Troms Steinbit (Tromso, Norway) were sent by air transportation from northern Norway to Québec, Canada. The eggs were at about 380 degree-day upon arrival. Periodic disinfections were performed regularly with glutaraldehyde $(150 \mathrm{ppm})$ according to protocols established by Hansen and Falk-Petersen (2001b). Individual egg masses were incubated in upwelling incubators at 5 ${ }^{\circ} \mathrm{C}$ until hatching. The hatching success of the three egg masses were 53,36 , and $23 \%$ hatching was completed in a week. Newly hatched fish (mean weight $0.10 \pm 0.010 \mathrm{~g}$ and mean length 24.5 $\pm 1.41 \mathrm{~mm}$ ) from all families were evenly mixed and 40 fish, randomly placed in each of the 27 low-level rearing units (1.5 L volume) with a water supply of $0.5 \mathrm{~L} / \mathrm{min}$ with low water depth (2 $\mathrm{cm}$ ) in order to facilitate feed ingestion (Strand et al., 1995). Average salinity was $30.4 \pm 0.38 \%$ and oxygen saturation was always above $80 \%$ (mean $97 . \pm 5.5 \%$ ). Light intensity was between 800-1000 lux and a 12/12-h light/dark cycle was adopted. Fish were reared at three different temperatures $\left(5^{\circ} \mathrm{C}\right.$ : $5.2 \pm 0.75{ }^{\circ} \mathrm{C}, 8{ }^{\circ} \mathrm{C}: 8 \pm 0.25{ }^{\circ} \mathrm{C}$, and $12{ }^{\circ} \mathrm{C}$ : $\left.11.5 \pm 0.82{ }^{\circ} \mathrm{C}\right)$ and randomly assigned to the different diets at each temperature in triplicates ( 3 diets $\mathrm{X} 3$ temperature $\mathrm{X} 3$ replicates $=27$ units). The fish assigned to $8{ }^{\circ} \mathrm{C}$ and $12{ }^{\circ} \mathrm{C}$ were gradually acclimated to their respective temperature $\left(1{ }^{\circ} \mathrm{C}\right.$ per hour). On a daily basis, mortalities were recorded, dead fish removed and rearing units carefully cleaned by displacement of the rearing baskets in supplemental water baths, in order to limit stress during cleaning operations. Initially, fish were fed on Artemia in combination with experimental diets each hour for the first two weeks posthatching to promote feeding behaviour and secure the experiment, then were fed only on compound diet. Fish were hand-fed daily in excess (approximately $1 \mathrm{~g}$ per day in each tank) every hour from 8:00 to $17: 00 \mathrm{pm}$. and a concentration of 500 artemia /L was manually distributed eight times per day in each experimental unit. The composition of the three diets (Control, $\mathrm{PH}_{10 \%}$ and $\mathrm{PH}_{20 \%}$ ) (formulated and processed at INRA-IFREMER, Centre de Brest, France) is detailed in Table 1.

The experimental diets were isoproteinic, isolipidic and isoenergetic. They differed only in the molecular form of a part of the protein fraction, control diet containing only native protein, diet $\mathrm{PH}_{10 \%}$ and $\mathrm{PH}_{20 \%}$ containing 10 and 20\% of hydrolysed protein (Table 1). The PH used, Asta$\mathrm{Pep}^{\mathrm{MC}}$ was made by an enzymatic hydrolysis of shrimp (Pandalus borealis) waste, and was provided by ABK-Gaspésie inc. (Matane, QC, Canada). Amino acid profile was established using the Waters AccQTag method (liquid chromatography (HPLC) with fluorescence detection). Peptide molecular weight distribution was obtained using a Superdex peptide column 10/300GL (Amersham Biosciences), followed by HPLC (Waters 600) analysis. The formulated feeds were processed as follow: ingredients were mechanically mixed with water, pelletized and dried at 50 
${ }^{\circ} \mathrm{C}$ for 20 min (Cahu et al., 1999). The pellets were sieved to obtain different particle size of 200400, 400-600, 600-800, 800-1000, and 1000-1200 $\mu \mathrm{m}$. Different sizes were given to the fish depending on their length using this formulae: Particule size $(\mu \mathrm{m})=$ Length of the larvae $(\mathrm{mm}) \cdot 25$. Each new size were gradually introduced in combination with the previous size over a few days.

Fish were sampled at 6 occasions over 60 days (day 15 ( $n=5$ per replicate), 20 ( $n=3), 30$ ( $n=3$ ), 48 $(n=3)$ and $60(n=3))$. Fish were fasted for 18 hours before sampling. Individual weights and lengths were noted and the fish quickly frozen at $-80^{\circ} \mathrm{C}$ for use in a complementary experiment. Survival rate was calculated by withdrawing total dead individuals from initial number each day. Results are presented as cumulative mortalities over 60 days.

Specific growth rate (SGR) and condition factor (CF)

SGR was calculated as follows:

SGR $\left(\% \cdot\right.$ day $\left.^{-1}\right)=\left(\ln \mathrm{W}_{\mathrm{t} 2}\right)-\left(\ln \mathrm{W}_{\mathrm{t} 1}\right) \cdot(\text { experimental time in days })^{-1} \times 100$. $^{-1}$

Where $\mathrm{W}_{\mathrm{t} 1}$ is mean weight ( $\mathrm{g}$ ) of the fish at hatching, $\mathrm{W}_{\mathrm{t} 2}$ is mean final weight of the fish.

Condition factor (CF) was calculated according to the following formula (Bagenal and Tesch, 1978; Bolger and Connolly, 1989):

$\mathrm{CF}=100\left(\mathrm{~W} / \mathrm{L}^{\mathrm{n}}\right)$

where $\mathrm{W}=$ weight $(\mathrm{g}), \mathrm{L}=$ length $(\mathrm{cm})$ and $\mathrm{n}=$ slope of the logarithmic length-weight equation. The value of " $n$ " calculated for wolffish was 3.24 for the duration of the experiment.

Statistical analysis

Mean SGR, survival and CF were compared for each diet within a single temperature by analysis of variance using the general linear model procedure in the Systat 10.2 computer software (SPSS inc., 2002). When no significant difference was detected between the diet groups at a given temperature, groups were pooled and compared to the other temperature. When a significant difference was detected, a Tuckey post-hoc test was used (ZAR, 1984). Treatments were considered significantly different when $\mathrm{P}<0.05$. The data were tested for homogenous variation and normal distribution prior to the analyses.

\section{Results}

The amino acid profile of protein hydrolysate showed that the essential amino acids were largely represented. Especially lysine and methionine that corresponded to 7 and $1.8 \%$ of total amino acids (Table 2). The molecular weight distribution showed that $\mathrm{PH}$ was composed of $25 \%$ peptides with less than 50 amino acids, 65\% peptides having between 50 and 500 amino acids, and 10\% peptides composed with more than 500 amino acids (Figure 1).

Our results indicate that at all rearing temperatures, $\mathrm{PH}$ does not have any significant effect on survival, SGR or CF ( $>0.05$ ) (Table 3) suggesting that the experimental diets induced similar growth performances and nutritional status at any given temperature. In general, for a given temperature and diet, variability was quite high between and within replicates. 
Growth trials at different temperature (pooled results) indicate that survival from hatching to day 60 , was significantly lower for groups at $12{ }^{\circ} \mathrm{C}\left(52,54\right.$, and $34 \%$ at 5 , 8, and $12{ }^{\circ} \mathrm{C}$ respectively; $\mathrm{p}<0.001$ ) (figure 2). Visual observations during the feeding trials showed that food ingestion

behaviour was fully established at day 12. Mortalities observed always corresponded to nonfeeding individuals. Peak mortalities due to starved individuals contribution occurred at day 16 , 23 and 30 and stabilized at day 28, 42 and 53 respectively for groups at 12, 8, $5{ }^{\circ} \mathrm{C}$ (Figure 2).

We obtained increasing SGR with increasing temperatures. Overall SGR from day 0 to day 60 of 1.97, 4.01 and $4.88 \%$ /day were achieved at 5, 8 and $12{ }^{\circ} \mathrm{C}$ respectively. Growth rates at different stages were also calculated and data are presented in figure 3.

\section{Discussion}

The mean SGRs calculated at the different temperatures in the present study are in accordance with our review of the literature (Hansen and Falk-Petersen, 2002; Hansen and Falk-Petersen, 2001; Falk-Petersen et al., 1999). Those results are an indication that our experimental diets, containing 58\% protein and $16 \%$ lipid were suitable for this species.

The negative SGR obtained from day 0-15 are probably reflecting the large proportion of starved individuals in which a loss of weight was noticeable. Those individuals eventually died and the calculated SGR was no longer influenced by the reduced weight of the non-feeding individuals. Larvae grew better at higher temperature from day 15-20 and day 20-30. At day 30-60, SGR were slightly higher at 8 than $12^{\circ} \mathrm{C}$. This is in accordance with the results of Hansen and FalkPetersen (2002) who obtained better growth when water temperature was regulated to $8{ }^{\circ} \mathrm{C}$ compared with 10 or $12^{\circ} \mathrm{C}$ from day 30 post-hatch. According to our results and previous research, it is therefore proposed that wolffish be reared at $8{ }^{\circ} \mathrm{C}$ for the entire juvenile period if we consider the high mortality rates encountered at $12{ }^{\circ} \mathrm{C}$ and the reduced growth rate at $4{ }^{\circ} \mathrm{C}$.

The first 12 days post-hatching, most larvae were lying on the bottom of the tank and did not display active feeding behaviour. This was also observed by Strand et al. (1995) in a closely related species (A. lupus) in the first 6 days post-hatch. The mortalities observed always corresponded to the smallest non-feeding individuals that were lying on the bottom of the tank. This is an indication, as proposed by Strand et al. (1995), that the failure to initiate feeding may be the main cause of mortality and not to the unsuitability of the diets. Falk-Petersen et al. (1999) observed by histological examinations that wolffish larvae that never start exogenous feeding often present abnormalities of the mucosa cells of the digestive tract. No feeding individuals died during the 60 days of the experimental period nor after.

Statistical analyses indicate no effect of $\mathrm{PH}$ on survival and growth, however we can not conclude that $\mathrm{PH}$ have no effects on newly hatched wolffish. We obtained highly variable results among replicates that likely precluded us from seeing significant differences. We observed that the highest survival is always achieved by the groups given the PH20 diet at all temperature. Also, the use of Artemia in combination with the formulated diets in the first two weeks might have limited the appearance of marked difference in survival rates by smoothing the eventual difference induced by the diets.

Protein hydrolysates supplementation is reported to yield highly variables results among different studies even in closely related species. For instance, some studies have shown that PH enhanced 
growth of salmon fry (Salmo salar) (Berge and Storebakken, 1996), post-smolt Atlantic salmon (Refstie et al., 2004) and carp larvae (Cyprinus carpio) (Carvalho et al., 1997). Cahu and Zambonino-Infante (1999) observed a better survival and growth of Sea bass when a moderate proportion of PH was included in the feed (Cahu and Zambonino-Infante, 1998) ZamboninoInfante et al. (1999). Another study showed that inclusion of PH in the diet somewhat improved growth and survival (not statistically significant) of Atlantic halibut larvae compared to the control diet (Kvâle et al., 2002). A positive effect of dietary protein hydrolysates on growth and survival has been reported only on larval stages in literature. At the opposite, no or negative effects was reported on juvenile rainbow trout (Hardy et al. 1983, Stone et al. 1989) and turbot (Oliva Teles et al., 1999). We tentatively suggest that the absence of a significant beneficial effect of PH may be linked to the relatively advanced stage of wolffish at hatching. Wolffishes hatch with a morphology more characteristic of a juvenile i.e. they display external morphology and internal organs that are not typical of a larval fish (Falk-Petersen and Hansen, 2001). The stomach and gastric glands is formed many weeks before hatching in wolffish (Falk-Petersen and Hansen, 2001). On the other hand, many fish species begin exogenous feeding before the onset of a fully functional digestive system and larval fish generally display poor assimilation efficiency for protein (Ronnestad et al., 2001). Furthermore, metamorphic species present an undifferentiated digestive system which appear as a straight tube at hatching (Kolkovski, 2001; Gisbert, 2004 ; Hamlin et al., 2000). The stomach development is achieved at day 15 post-hatch in sea bass (Walford and Lam, 1993), at day 22 post-hatch in Dover sole (Solea solea) (Bouhlic and Gabaudan, 1992), and gastric glands appears at day 25 post-hatched in European sea bass (Zambonino-Infante and Cahu, 2001) and at day 22 post-hatch in sole even though no pepsin activity has been observed after 5 weeks post-hatching (Bouhlic and Gabaudan, 1992).

Day et al. (1997) and Cahu and Zambonino-Infante, (2001) suggest that PH are beneficial to fish larvae but have no effects or can even depress growth of juvenile fish. Pancreatic proteolytic enzymes (e.g. trypsin) are generally low at the onset of first-feeding in most fish larvae and only enhanced at metamorphosis (Gawlicka et al., 2000, Cahu and Zambonino-Infante, 2001). Wolffish have well developed endo- and exocrine pancreatic tissue at hatching (Falk-Petersen and Hansen, 2001). Wolffish also present tryptic activity well before hatching (activities of up to 3.41 and $6.73 \mathrm{U} / \mathrm{g} * 10^{-4}$ protein at 340 and 900 degree-day respectively) (Desrosiers et al., in preparation). Furthermore, Lamarre et al. (2004) suggested that trypsin activity levels at hatch could be used as an indicator of growth and survival in a closely related species (‥ lupus).

The PH biochemical composition was examined in order to explain the absence of PH effect. The amino acid composition of PH was very close to that of fish meal (Zambonino Infante et al. 1997) and well suited to support larval growth. But the peptide sizes of PH were very large compared to those used in other studies. Indeed, in our study, $65 \%$ of the peptides were composed of 50 to 500 amino acids, when an effect was evidenced in sea bass larvae with di-and tri-peptides (Zambonino Infante et al., 1997) and 20 amino acid peptides (Cahu et al., 1999). It can be suggested that the degree of hydrolysis of the PH used was insufficient to induce a specific digestive enzyme stimulation for promoting larval growth.

Another hypothesis would be that the precocious ontogeny of the digestive tract of the wolffish is particularly well-suited for protein digestion at first-feeding compared to metamorphic species. Their fully functional digestive system would enable wolffish to digest intact proteins efficiently. Further experiment, conducted with short peptides would test these two hypotheses. 


\section{Acknowledgements}

This work was financed by the MAPAQ, FQRNT and the research network AquaNet (project no. AP34 Blier/Le François et al.). The authors would like to express their gratitude to Dr. Lucie Beaulieu for the amino acid profile analysis and to M. Simon Lamarre, François Veaux and Bruno Archer for their assistance throughout the experiment. We gratefully acknowledge the anonymous referees for their valuable comments on an earlier version of this manuscript.

\section{References}

Bagenal, T., Tesh, R., 1978. Age and Growth In: Bagenal, T. (Ed), Methods for assessment of fish production in fresh water. IBP Handbook No. 3, second ed. Blackwell Scientific, Oxford.

Berge, G. M., Storebakken T., 1996. Fish protein hydrolysate in starter diets for Atlantic salmon (Salmo salar) fry. Aquaculture 145, 205-212.

Blier, P., Pelletier, D., Dutil, J-D., 1997. Does aerobic capacity set a limit on fish growth rate? Rev. Fish. Sci. 5, 323-340.

Bolger, T., Connolly, P.L., 1989. The selection of suitable indexes for the measurement and analysis of fish condition. J. Fish. Biol. 34, 171-182.

Bouhlic, M., Gabaudan, J., 1992. Histological study of the organogenesis of the digestive system and swim bladder of the Dover sole Solea solea. Aquaculture 102, 373-396.

Busacker, G.P., Adelman, I.R., Goolish, E.M., 1990. Growth. In:Schreck, C.B., Moyle, P.B. (Eds) Methods For Fish Biology, American Fisheries Society, Bethesda, Maryland, USA. pp. 363-387.

Cahu, C., Zambonino-Infante, J., 2001. Substitution of live food by formulated diets in marine fish larvae. Aquaculture 200, 161-180.

Cahu, C. L., Zambonino-Infante, J.L., Quazuguel, P., Le Gall, M. M., 1999. Protein hydrolysate vs fish meal in compound diets for 10-day old sea bass Dicentrarchus labrax larvae. Aquaculture 171, 109-119.

Cahu, C. L., Zambonino-Infante, J.L., 1995. Maturation of the pancreatic and intestinal digestive functions in sea bass (Dicentrarchus labrax) effect of weaning with different protein sources. Fish Physiol. Biochem. 14, 431-437.

Carvalho , A. P., Escaffre A.-M., Oliva Teles A., Bergot P., 1997. First feeding of common carp larvae on diets with high levels of protein hydrolysates. Aquacult. Int. 5, 361-367.

Day, O. J., Howell B.R., Jones, D.A., 1997. The effect of dietary hydrolysed fish protein concentrate on the survival and growth of juvenile Dover sole, Solea solea (L.), during and after weaning. Aquacult. Res. 28, 911-921. 
de la Higuera, M., 2001. Effects of nutritional factors and feed characteristics on feed intake. In, Houlinan, D., Boujard, T., et Jobling, M. (Eds.), Food intake in fish. Blackwell Science, Oxford, UK, pp.131-156.

Falk-Petersen, I. B., Hansen, T. K. Fieler, R., Sunde, L. M., 1999. Cultivation of the spotted wolffish Anarhichas minor (Olafsen) - a new candidate for cold-water fish farming. Aquacult. Res. 30 (9), 711-718.

Falk-Petersen, I. B., Hansen T.K., 2001. Organ differentiation in newly hatched common wolfish. J. Fish Biol. 59 (6), 1465-1482.

Foss, A., Imsland, A.K., Falk-Petersen, I.B., Oiestad, V., 2004. A review of the culture potential of spotted wolffish Anarhichas minor Olafsen. Rev. Fish. Biol. Fisher. 14, 277-294.

Gawlicka, A., Parent, B., Horn, M.H., Ross, N., Opstad, I., Torrissen, O.J., 2000. Activity of digestive enzymes in yolk-sac larvae of Atlantic halibut (Hippoglossus hippoglossus): indication of readiness for first-feeding. Aquaculture 184, 303-314.

Gisbert, E., Sarasquete, M.C., Williot, P., Castello-Orvay, F., 1999. Histochemistry of the development of the digestive system of Siberian sturgeon during early ontogeny. J. Fish Biol. 55, 596-616.

Gisbert, E., Piedrahita, R.H., Conklin, D.E., 2004. Ontogenetic development of the digestive system in California halibut (Paralichthys californicus) with notes on feeding practices. Aquaculture 232, 455-470.

Hamlin, H.J., von Herbing, I.H., Kling, L.J., 2000. Histological and morphological evaluations of the digestive tract and associated organs of haddock throughout post-hatching ontogeny. J. Fish Biol. 57, 716-732.

Hansen, T.K., Falk-Petersen, I.B., 2002. Growth and survival of first-feeding spotted wolffish (Anarhichas minor Olafsen) at various temperature regimes. Aquacult. Res. 33(14), 1119-1127.

Hansen, T.K., Falk-Petersen, I.B., 2001. The influence of rearing temperature on early development and growth of spotted wolffish Anarhichas minor (Olafsen). Aquacult. Res. 32(5), 369-378.

Hansen, T.K., Falk-Petersen, I.B., 2001b. Effects of egg disinfection and incubation temperature on early life stages of spotted wolffish. Aquacult. Int. 9(4), 333-344.

Hardy, R.W., 2000. Fish feeds and nutrition - Fish protein hydrolysates as components in feeds. Aquacult. Mag. 26(5), 62-66.

Hardy, R.W., Shearer, K.D., Stone, F.D., Wieg, D.H., 1983. Fish silage in aquaculture diets. J. Wold Mar. Soc. 14, 695-703. 
Houlihan, D.F., Hall, S.J., Gray, C., Noble, B.S., 1988. Growth rates and protein turnover in atlantic cod, Gadus morhua. Can. J. Fish. Aquat. Sci. 45, 951-964.

Kolkovski, S. 2001. Digestive enzymes in fish larvae and juveniles - implications and applications to formulated diets. Aquaculture 200, 181-201.

Koven, W., Rojas-Garcia, C.R., Finn, R.N., Tandler, A., Roennestad, I., 2002. Stimulatory effect of ingested protein and/or free amino acids on the secretion of the gastro-endocrine hormone cholecystokinin and on tryptic activity, in early-feeding herring larvae, Clupea harengus. Marine Biology 140, 1241-1247.

Kristinsson, H.G., Rasco, B.A., 2000. Fish protein hydrolysates: Production, biochemical, and functional properties, Crit. Rev. Food Sci. Nut. 40(1), 43-81.

Kvâle, A., Harboe, T., Naess, T., Hamre, K., 2002. Effect of pre-digested protein on growth and survival of Atlantic halibut larvae (Hippoglossus hippoglossus L.). Aquacult. Res. 33, 311-321.

Lamarre, S.G., Le Francois, N.R., Falk-Petersen, I-B., Blier, P.U., 2004. Can digestive and metabolic enzyme activity levels predict growth rate and survival of newly hatched Atlantic wolffish (Anarhichas lupus)? Aquacult. Res.35, 608-613.

Le François N.R., Lemieux H., Blier P.U. 2002. Biological and technical evaluation of the potential of marine and anadromous fish species for cold-water mariculture. Aquacult. Res. 33, 95-108.

Lemieux, H., Blier, P.U., Dutil, J.D., 1999. Do digestive enzymes set a physiological limit on growth rate and food conversion efficiency in the Atlantic cod (Gadus morhua)? Fish Physiol. Biochem. 20(4), 293-303.

Li, D.F., Zhao, X.H., Yang, T.B., Johnson, E.W., Thacker, P.A., 1999. A comparison of the intestinal absorption of amino acids in piglets when provided in free form or as dipeptides. AsianAustralas. J. Anim. Sci. 12, 939-943.

Lopez-Alvarado, J., Langdon, C.J., Teshima, S.I., Kanazawa, A., 1994. Effects of coating and encapsulation of crystalline amino acids on leaching in larval feeds. Aquaculture 122, 335-346.

Refstie, S., Olli, J.J., Standal, H., 2004. Feed intake, growth, and protein utilisation by post-smolt

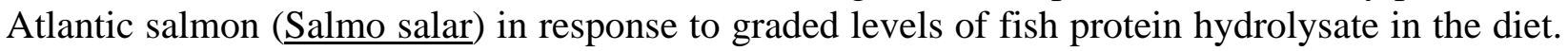
Aquaculture 239, 331-349.

Rojas-Garcia, C.R., Roennestad, I., 2003. Assimilation of dietary free amino acids, peptides and protein in post-larval Atlantic halibut (ippoglossus hippoglossus). Mar. Biol. 142, 801-808.

Roennestad, I., Rojas-Garcia, C. R. Tonheim, S. K., Conceicao, L. E. C., 2001. In vivo studies of digestion and nutrient assimilation in marine fish larvae. Aquaculture 201, 161-175. 
Rust, M.B., 1995. Quantitative aspects of nutrient assimilation in six species of fish larvae. Ph.D. Thesis, School of Fisheries, University of Washington, Seattle.

Sharma, J.G., Chakrabarti, R., 1999. Larval rearing of common carp Cyprinus carpio: A comparison between natural and artificial diets under three stocking densities. J. World Aquacult. Soc. 30(4), 490-495.

Silk, D.B.A., Grimble, G.K., Rees, R.G., 1985. Protein digestion and amino acid and peptide absorption. Proc. Nut. Soc. 44, 63-72.

Strand, H.K., Hansen, T.K., Pedersen, A., Falk-Petersen, I.B., Oiestad, V., 1995. First feeding of common wolffish on formulated dry feed in a low water-level raceway system. Aquacult. Int. 3, $1-10$.

Stone, F.D., Hardy, R.W., Shearer, K.D., Scott, T.M., 1989. Utilization of fish silage by Rainbow trout (Salmo gairdneri). Aquaculture 76, 109-118.

Szlaminska, M., Escaffre, A.M., Charlon, N., Bergot, P., 1993. Preliminary data on semisynthetic diet for goldfish (Carassius auratus L.) larvae. In: Kaushik S.J., Luquet, P. (Eds) Fish nutrition in Practice, INRA, Paris (Les Colloques 61) pp. 606-612

Walford, J., Lam, T.J., 1993. Development of digestive tract and proteolytic enzyme activity in sea bass Lates calcarifer larvae and juveniles. Aquaculture 109, 187-205.

Zambonino-Infante, J.L. and Cahu, C.L., 1994. Development and response to a diet change of some digestive enzymes in sea bass (Dicentrarchus labrax) larvae. Fish Biochem. Physiol. 12, 399-408.

Zambonino-Infante, J.L. and Cahu, C.L., 2001. Ontogeny of the gastrointestinal tract of marine fish larvae, Comp. Biochem. Physiol. C 130 (4), 477-487.

Zambonino Infante J.L., Cahu C. and Péres A., 1997. Partial substitution of native protein by diand tripeptides in diet improves sea bass (Dicentrarchus labrax) larvae development. J.Nutr., 127: 608-614.

Zambonino Infante, J.L., Cahu, C.L., Peres, A., 1997. Partial substitution of di- and tripeptides for native proteins in Sea bass diet improves Dicentrarchus labrax larval development. J. Nut. 127(4), 608-614.

Zar, J.H., 1984. Biostatistical analysis. Prentice Hall, Englewood Cliffs, New Jersey. 


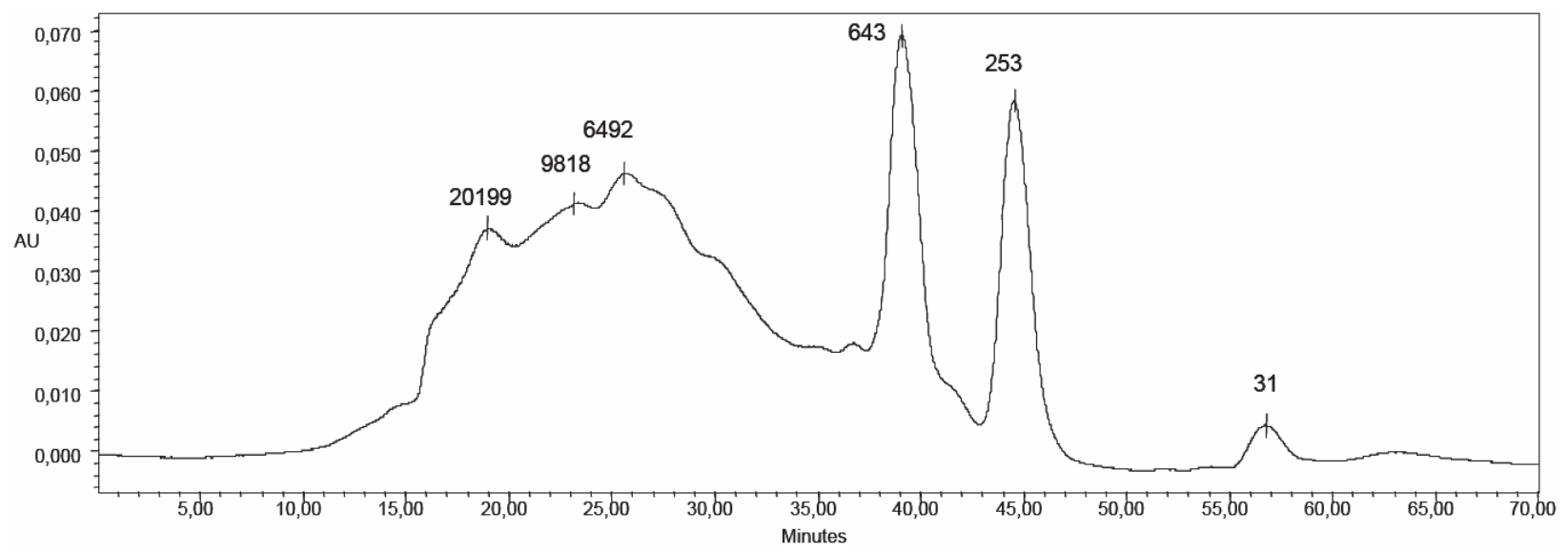

Fig. 1. Survival of the wolffish reared at different temperatures.

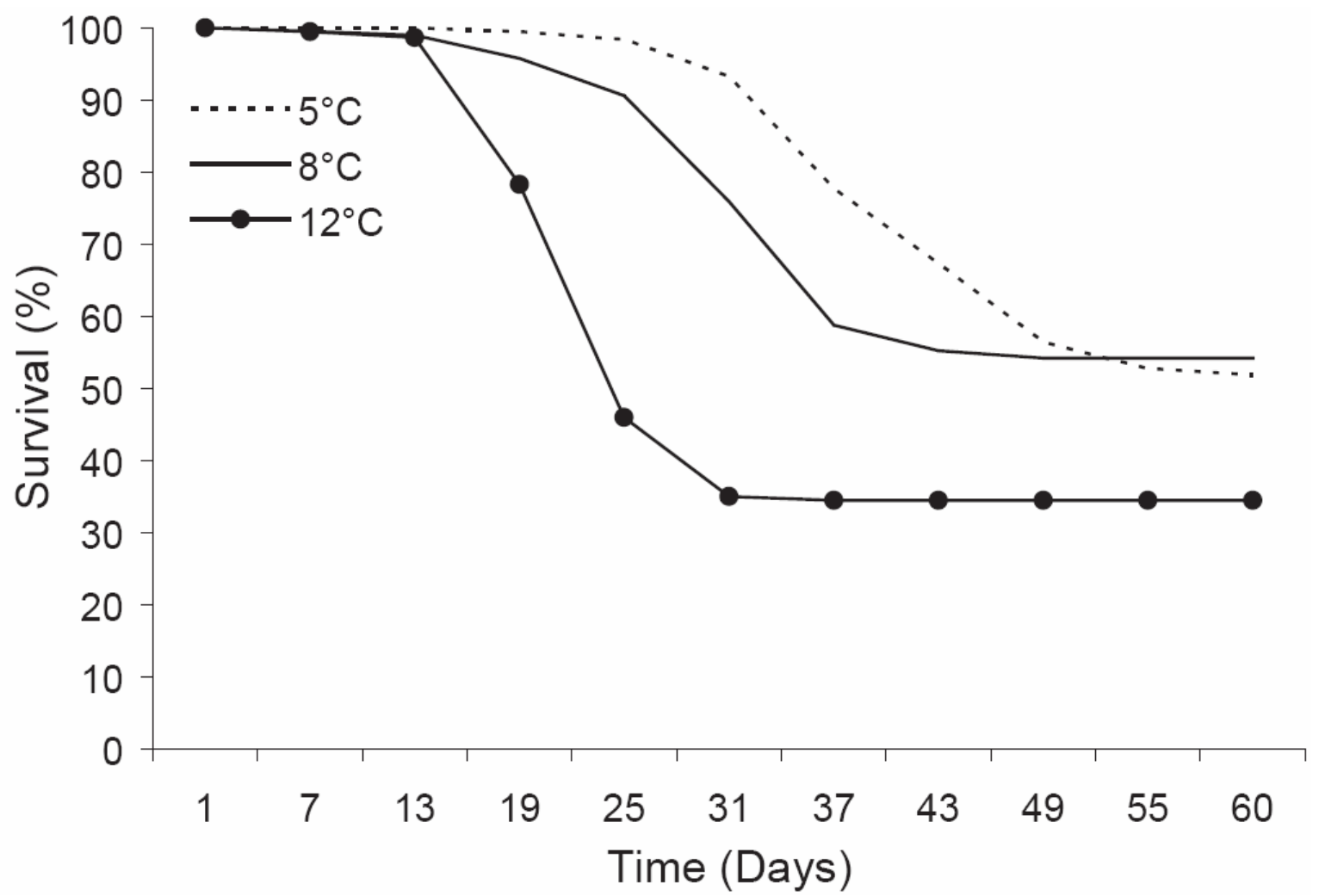

Fig. 2. Specific growth rate of spotted wolffish reared at different temperature from hatching to day 60. 


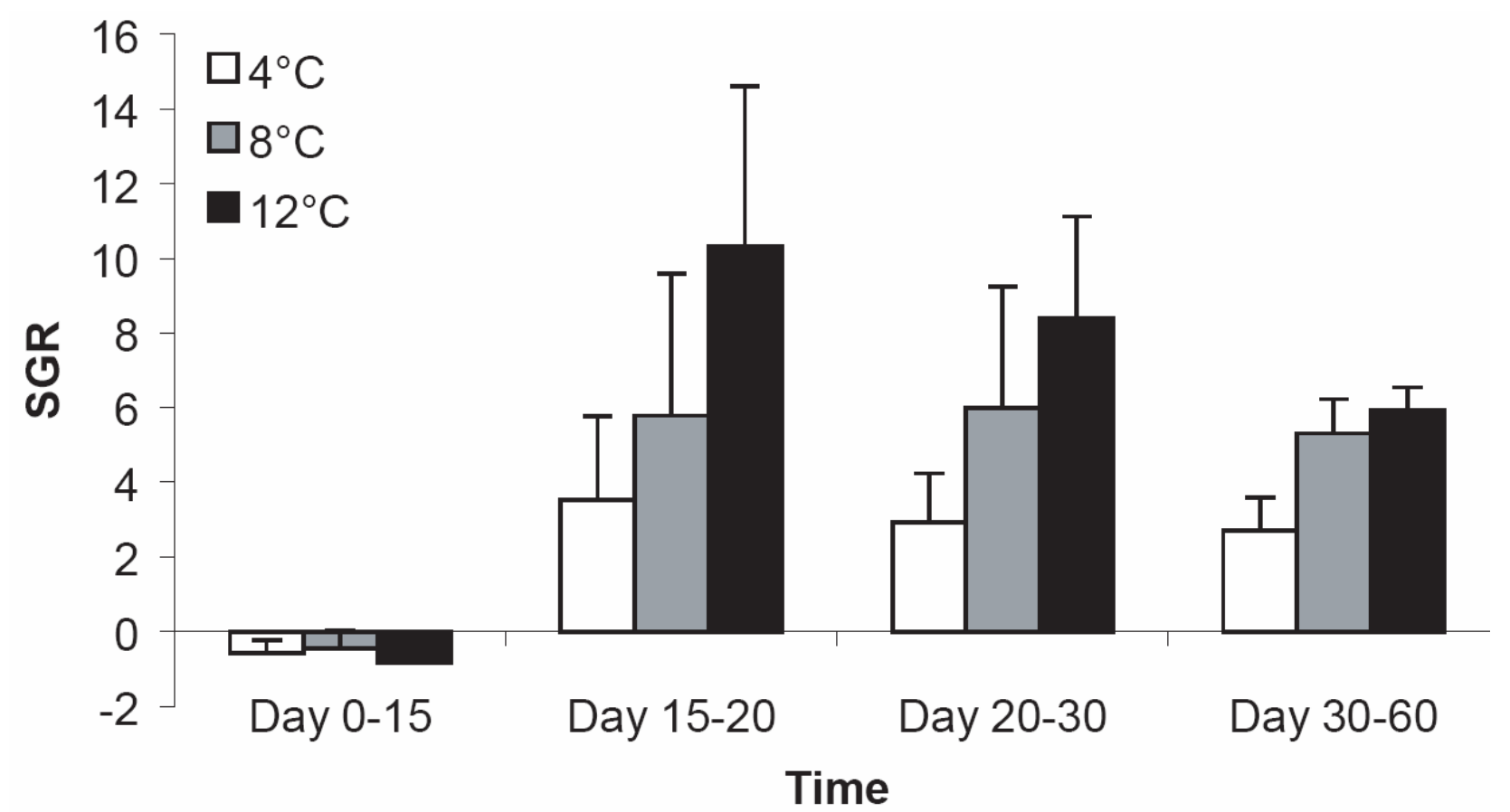

Fig. 3 
Table 1. Percent composition of the experimental diets.

\begin{tabular}{|c|c|c|c|}
\hline Ingredients ${ }^{1}$ (in \%) & Control & $\mathbf{P H}_{10}$ & $\mathbf{P H}_{20}$ \\
\hline Fish meal LT & 74 & 64 & 54 \\
\hline Protein hydrolysates ${ }^{2}$ & - & 10 & 20 \\
\hline Precooked potato starch & 5 & 5 & 5 \\
\hline Cod liver oil & 3 & 3 & 3 \\
\hline Soy lecithin & 5 & 5 & 5 \\
\hline Vitamin Mixture $^{3}$ & 8 & 8 & 8 \\
\hline Mineral Mixture $^{4}$ & 4 & 4 & 4 \\
\hline Betaine & 1 & 1 & 1 \\
\hline Moisture & 7.8 & 8.8 & 7.4 \\
\hline Protein (N X6.25)/d.m. & 58.2 & 58.0 & 57.2 \\
\hline Lipid/d.m. & 16.4 & 16.6 & 16.8 \\
\hline Ash/d.m. & 12.8 & 13.7 & 13.9 \\
\hline
\end{tabular}

${ }^{1}$ Dietary ingredients were commercially obtained. Fish meal, and cod liver oil were from $\mathrm{La}$ Lorientaise (Lorient, France). The soy lecithin was from Ets Louis François (St Maur des Fossés, France). The precooked potato starch (Nutralys) was from Roquette (Lille, France). Asta-pep: ABK Gaspésie (Matane, QC, Canada).

${ }^{2}$ Asta-Pep: Total carotenoids $550 \pm 10 \mathrm{ug} / \mathrm{g}$, proteins $65.8 \pm 1.5 \% /$ dry product, ash $6.9 \pm 0.2 \%$ /dry product, total lipid $20.4 \pm 1.5 \%$ /dry product.

3 Per kg of diet: retinyl acetate $80 \mathrm{mg}$; cholecalciferol $0.2 \mathrm{mg}$; all-rac- $\alpha$-tocopherol acetate $800 \mathrm{mg}$; menadione $80 \mathrm{mg}$; thiamin $80 \mathrm{mg}$; riboflavin $22 \mathrm{mg} ; \mathrm{D}-$ calcium pantothenate 160mg; pyridoxine $\mathrm{HCl} 24 \mathrm{mg}$; cyanocobalamin $80 \mathrm{mg}$; niacin 80mg; choline chloride 16g; ascorbic acid 1.6g; folic acid 8mg; biotin 80mg; meso-inositol 2.4g.

4Per kg of diet: $\mathrm{KCl} 3.6 \mathrm{~g} ; \mathrm{KI} 1.6 \mathrm{mg} ; \mathrm{CaHPO}_{4} \cdot 2 \mathrm{H}_{2} \mathrm{O} 20 \mathrm{~g} ; \mathrm{NaCl} 1.6 \mathrm{~g} ; \mathrm{CuSO}_{4} \cdot 5 \mathrm{H}_{2} \mathrm{O}$ 120mg; $\mathrm{ZnSO}_{4} \cdot 7 \mathrm{H}_{2} \mathrm{O}$ 160mg; $\mathrm{CoSO}_{4} \cdot 7 \mathrm{H}_{2} \mathrm{O} 0.8 \mathrm{mg} ; \mathrm{FeSO}_{4} \cdot 7 \mathrm{H}_{2} \mathrm{O}$ 800mg; $\mathrm{MnSO}_{4} \cdot \mathrm{H}_{2} \mathrm{O}$ 120mg; $\mathrm{CaCO}_{3}$ 8.6g; $\mathrm{MgSO}_{4} \cdot 7 \mathrm{H}_{2} \mathrm{O}$ 4.96g; NaF 40mg. 
Table 2. Essential amino acid composition of the fish meal LT and protein hydrolysate utilized in the fabrication of the diets (in g per 100g protein)

\begin{tabular}{lcc}
\hline $\begin{array}{l}\text { Indispensable amino acids } \\
\text { (essentials) }\end{array}$ & Fish meal LT & Protein hydrolysates \\
Arginine & 5.6 & 7.5 \\
Histidine & 1.8 & 2.9 \\
Isoleucine & 4.1 & 4.7 \\
Leucine & 6.7 & 7.7 \\
Lysine & 6.0 & 7.0 \\
Méthionine & 2.4 & 1.8 \\
Phénylalanine & 6.0 & 6.2 \\
Thréonine & 2.6 & 6.6 \\
Tryptophan & 0.8 & 1.2 \\
Valine & 4.4 & 4.8 \\
\hline
\end{tabular}


Table 3 Molecular weight distribution (percent of total area) from size exclusion chromatography of protein hydrolysates

\begin{tabular}{cc}
\hline $\begin{array}{c}\text { Molecular } \\
\text { weight (Da) }\end{array}$ & $\begin{array}{c}\text { Approximative } \\
\text { area (\%) }\end{array}$ \\
\hline 31 & 1.37 \\
253 & 13.29 \\
643 & 7.50 \\
6492 & 45.20 \\
9818 & 21.06 \\
20199 & 9.63 \\
$>20199$ & 1.31 \\
\hline
\end{tabular}

Approximative area was calculated as percentage of total area for each peak observed on the chromatograph 
Table 4 Mean percent survival, specific growth rate (\%/day) and condition factor (CF) of wolfish in relation to rearing temperature and diet treatment at day 60 post-hatch.

\begin{tabular}{|c|c|c|c|c|c|c|c|c|c|}
\hline $\mathbf{T}^{\circ}$ & & $5^{\circ} \mathrm{C}$ & & & $8^{\circ} \mathrm{C}$ & & & $12^{\circ} \mathrm{C}$ & \\
\hline Diet & Control & $\mathbf{P H}_{10}$ & $\mathbf{P H}_{20}$ & Control & $\mathbf{P H}_{10}$ & $\mathbf{P H}_{20}$ & Control & $\mathbf{P H}_{10}$ & $\mathbf{P H}_{20}$ \\
\hline Survival & $51.6 \pm 1.8$ & $51.2 \pm 7.6$ & $53.7 \pm 17$ & $49.7 \pm 16.3$ & $53.3 \pm 13.5$ & $59.4 \pm 9.6$ & $33.9 \pm 6.3$ & $32.3 \pm 6$ & $37 \pm 3.2$ \\
\hline SGR & $2.1 \pm 0.3$ & $1.7 \pm 0.6$ & $2.1 \pm 0.6$ & $4.1 \pm 0.4$ & $3.7 \pm 0.4$ & $4.2 \pm 0.5$ & $5.1 \pm 0.1$ & $4.4 \pm 0.5$ & $5 \pm 0.7$ \\
\hline CF & $0.73 \pm 0.16$ & $0.65 \pm 0.04$ & $0.61 \pm 0.04$ & $0.67 \pm 0.14$ & $0.60 \pm 0.09$ & $0.59 \pm 0.05$ & $0.58 \pm 0.03$ & $0.55 \pm 0.17$ & $0.55 \pm 0.04$ \\
\hline
\end{tabular}

Expressed as mean \pm standard deviation; initial fish weight: $103.0 \pm 10.3 \mathrm{mg} ; \mathrm{n}=40$ individuals per replicate (3 replicates) 